\title{
THE ROLE OF GEOGRAPHY IN STARTING TEACHER TRAINING FOR INFANT AND PRIMARY EDUCATION IN I TALY
}

\author{
ANDREA GUARAN \\ University of Udine, Italy, Department of Human Sciences, e-mail: andrea.guaran@uniud.it
}

(Received: September 2012; in revised form: November 2012)

\begin{abstract}
In Italy, in order to practice teaching in pre-school and primary school, it is compulsory to have a specific degree in the Science of primary education. It is a five-year course that qualifies you for teaching in both cases and it is subdivided in three main steps: traditional disciplinary courses, laboratories connected to their corresponding courses (for instance, the course of Geography didactics includes the corresponding laboratory), and training activities. These latter ones are subdivided as well in indirect training that is coordinated by the supervisors of the internship and direct training, which is carried out within schools. The teaching of Geography, even if it is underestimated in terms of hours of class as compared to other disciplinary fields, turns out to be essential, since spatial and geographical education is part of the obligatory educational offer for education in pre-school and in primary school.
\end{abstract}

Keywords: pre-school and primary school teachers' training, teaching geography

\section{NTRODUCTI ON}

Since the end of the 1990s, in Italy, in order to teach in pre-school, to children from three to six years old, and from five to ten years old years in primary school, it is compulsory to graduate in the Science of primary education. Formerly, a degree was not necessary: pre-school teachers, as they were called until 2003, could teach after three years of teachers' training college, while primary school teachers needed a diploma issued by 
the teachers' training college, initially attained after four years, then after five years. Basically, the school graduation certificate, previously in the teachers' training college, then in the psychological-pedagogical high school, gave the right to access the elementary school, now called primary school.

\section{THE BACHELOR DEGREE IN SCI ENCE OF PRI MARY EDUCATION}

Since 1998, a specific degree program has started (Ministerial decree 26 May $1998^{1}$ ), initially for a period of four years, that is open to anyone who has a five years college diploma. The access, however, has always been planned in relation to the absorption capability of the schools on a regional basis. The Faculties of Science of Primary Education were opened in several universities, even more than one for each of the twenty administrative regions on the Italian territory.

Every student was supposed to choose between two courses of study, pre-school or primary, corresponding to the type of school in which he or she would teach in the future, pre-school or primary school. Of course, nothing made it impossible, after graduating in a specific course of teaching, for example as a teacher in primary school, to re-enroll in order to obtain also a degree in the other teaching course (teacher in pre-school), so that one could have more opportunities to find easily a job in the school field. Graduating also provided directly teaching qualification with no need of undergoing further educational curricula or sitting for other exams.

After the 2011-2012 academic year, following the reform (Ministerial decree on the $10^{\text {th }}$ of September $2010, n .249^{2}$ ), a new order of the master degree for primary education started, not divided into undergraduate degree and master degree. From a four-year course we shifted to a fiveyear course that, unlike the old organization, gives the right to teach both in pre-school and in primary school and it qualifies for the participation in recruitment initiatives, examination procedures and more. This substantial change, together with the complex process of structural reassessment that the Italian university and all orders and levels of the school have been experiencing in recent years, has also led to a considerable dwindling of the towns that provide this type of course.

\footnotetext{
1 Ministero dell'Università e della Ricerca Scientifica e Tecnologica, Criteri generali per la disciplina da parte delle Università degli ordinamenti dei corsi di laurea in Scienze della Formazione primaria e delle scuole di specializzazione per l'insegnamento nella scuola secondaria, 1998.

2 Ministero dell'Istruzione, dell'Università e della Ricerca, Definizione della disciplina dei requisiti e delle modalità della formazione iniziale degli insegnanti della scuola dell'infanzia, della scuola primaria e della scuola secondaria di primo e secondo grado, ai sensi dell'articolo 2, comma 416, della legge 24 dicembre 2007, n. 244.
} 
Table 1. Primary science education: curriculum*

\begin{tabular}{|c|c|c|c|}
\hline Year & Courses/ laboratories/ teaching training & $\begin{array}{l}\text { ECTS } \\
\text { credits }\end{array}$ & $\begin{array}{l}\text { Lab. } \\
\text { ECTS } \\
\text { credits }\end{array}$ \\
\hline $\begin{array}{l}\text { First } \\
\text { year }\end{array}$ & $\begin{array}{l}\text { General didactics, didactic technologies and laboratory } \\
\text { English laboratory } \\
\text { Historical research methods and history } \\
\text { General pedagogy and laboratory } \\
\text { Sociology of education } \\
\text { History of school } \\
\text { Evaluation of the learning achievement levels, educational } \\
\text { research and laboratory }\end{array}$ & $\begin{array}{l}12 \\
8 \\
8 \\
8 \\
8 \\
12\end{array}$ & $\begin{array}{l}2 \\
2\end{array}$ \\
\hline $\begin{array}{l}\text { Second } \\
\text { year }\end{array}$ & $\begin{array}{l}\text { Teaching of Italian literature and laboratory } \\
\text { Teaching of mathematics and laboratory } \\
\text { Biological and ecological science teaching and laboratory } \\
\text { General and applied hygiene } \\
\text { English Laboratory } \\
\text { Special education and laboratory } \\
\text { Developmental psychology and psychobiology } \\
\text { School training }\end{array}$ & $\begin{array}{c}12 \\
10 \\
12 \\
4\end{array}$ & $\begin{array}{l}1 \\
1 \\
1 \\
2 \\
2\end{array}$ \\
\hline $\begin{array}{l}\text { Third } \\
\text { year }\end{array}$ & $\begin{array}{l}\text { Teaching of geography and laboratory } \\
\text { Physics education and laboratory } \\
\text { English laboratory } \\
\text { Children's literature and laboratory } \\
\text { Child neuropsychiatry } \\
\text { Intercultural education and international education } \\
\text { Regional history } \\
\text { School training }\end{array}$ & $\begin{array}{l}8 \\
8 \\
8 \\
8 \\
5\end{array}$ & $\begin{array}{l}1 \\
1 \\
3 \\
1\end{array}$ \\
\hline $\begin{array}{l}\text { Fourth } \\
\text { year }\end{array}$ & $\begin{array}{l}\text { Teaching of art education and laboratory } \\
\text { Laboratory of educational technology } \\
\text { Laboratory of English } \\
\text { Italian linguistics and laboratory } \\
\text { Musicology, music teaching and laboratory } \\
\text { Theories and techniques of playing and physical education } \\
\text { and laboratory } \\
\text { School training } \\
\text { Student's choice credits ( } 8 \text { ECTS credits) }\end{array}$ & $\begin{array}{c}12 \\
8 \\
8 \\
7 \\
8\end{array}$ & $\begin{array}{l}1 \\
3 \\
2 \\
1 \\
1\end{array}$ \\
\hline $\begin{array}{l}\text { Fifth } \\
\text { year }\end{array}$ & $\begin{array}{l}\text { Special education and laboratory } \\
\text { Elements of chemistry and chemistry education } \\
\text { Laboratory of English } \\
\text { Development and psychopathology laboratory } \\
\text { Statistics and computing for educational professions and } \\
\text { laboratory } \\
\text { School training } \\
\text { English language suitability } \\
\text { Training activities for the final examination }\end{array}$ & $\begin{array}{l}8 \\
4 \\
8\end{array}$ & $\begin{array}{l}1 \\
1\end{array}$ \\
\hline Total & & $267^{\#}$ & 33 \\
\hline
\end{tabular}

* The subdivision per year refers to the course of study at the University of Udine.

\#24 ECTS credits of school training. 
The number of the available places changes every year and it is different from region to region, depending on the request from the labour market represented by school (pre-school and primary). For example, in the region of Friuli Venezia Giulia, in the only course activated, at the University of Udine, the places for the academic year 2013-2014 were approximately 120 and similarly in the two previous years.

The curriculum, formerly created independently by each university that could afford a fair margin of intervention, excepting some essential criteria given the peculiarities of the course of study, after the new reform has a quite rigid and uniform structure throughout the national territory, with the possibility of flexible interventions only for the year in which to insert a course (Table 1). Given the geographic interest of this contribution, we underline that in the University of Udine, where the writer of this paper has been working as a teacher, the teaching of Geography Didactics is carried out in the third year, while in other towns it is preferably taught in the second or in the fourth year.

Even though with a different redistribution through different years, it remains a big amount of hours of training: it is held both in an indirect mode in the university classrooms by the supervisors of training, who are attached in-service teachers, full or part time for the university, and in a direct mode, carried out by students directly in kindergartens and primary schools, under the guidance of the class teachers, who are called welcoming teachers. The indirect training develops at the university through information moments, discussion and revision in small groups on aspects of training objectives and issues identified in situations of direct training. The direct training in the first two years (second and third year of the course of study) takes place both in kindergarten and in primary school and in the third year (fourth year of the course of study) all training experience develops in pre-school, whereas in the fourth (fifth year of the course of study) only in primary school (Table 2).

Table 2. School training: types, hours and credits

\begin{tabular}{|c|c|c|c|}
\hline & Indirect training & $\begin{array}{l}\text { Direct training } \\
\text { (Pre-school) }\end{array}$ & $\begin{array}{l}\text { Direct training } \\
\text { (Primary school) }\end{array}$ \\
\hline $\begin{array}{l}\text { Second year } \\
\text { (4 ECTS credits) }\end{array}$ & $\begin{array}{c}50 \mathrm{~h} \\
2 \text { ECTS credits }\end{array}$ & $\begin{array}{c}25 \mathrm{~h} \\
1 \text { ECTS credit }\end{array}$ & $\begin{array}{c}25 \mathrm{~h} \\
1 \text { ECTS credit }\end{array}$ \\
\hline $\begin{array}{l}\text { Third year } \\
\text { (5 ECTS credits) }\end{array}$ & $\begin{array}{c}50 \mathrm{~h} \\
2 \text { ECTS credits }\end{array}$ & $\begin{array}{c}37.5 \mathrm{~h} \\
1.5 \text { ECTS credits }\end{array}$ & $\begin{array}{c}37.5 \mathrm{~h} \\
1.5 \text { ECTS credits }\end{array}$ \\
\hline $\begin{array}{l}\text { Fourth year } \\
\text { ( } 7 \text { ECTS credits) }\end{array}$ & $\begin{array}{c}75 \text { h } \\
3 \text { ECTS credits }\end{array}$ & $\begin{array}{c}100 \mathrm{~h} \\
4 \text { ECTS credits }\end{array}$ & \\
\hline $\begin{array}{l}\text { Fifth year } \\
\text { ( } 8 \text { ECTS credits) }\end{array}$ & $\begin{array}{c}75 \mathrm{~h} \\
3 \text { ECTS credits } \\
25 \mathrm{~h} \text { (training final } \\
\text { report) } \\
1 \text { ECTS credit }\end{array}$ & & $\begin{array}{c}100 \mathrm{~h} \\
4 \text { ECTS credits }\end{array}$ \\
\hline
\end{tabular}


During the hours of direct training, students realise observation activities, mainly concentrated in the first year, then of planning and finally also of teaching practice, of course only in some subject areas, usually in relation to matters within the competence of the welcoming teacher.

We underline also the laboratory hours that are integrated by many of the disciplinary courses, and that are always assigned to the corresponding lecturer of the course. As far as the teaching of the Didactics of Geography is concerned, there are 8 credits with the addition of a credit for the laboratory, which correspond to approximately 56/64 hours of lectures and 10/12 lab hours in presence. The minimum oscillation of time is another variable whose choice is at the discretion of each university.

\section{ATTENTI ON TOWARDS GEOGRAPHY}

On the one hand geographical knowledge has to have a place in the curriculum, since Geography is a subject taught in primary school and the spatial aspects of education are part of the learning goals provided for kindergarten, but it certainly occupies a rather marginal role in the context of the five years curriculum. In fact, out of a total of 276 credits reserved to teaching and laboratories, only $9(8+1)$ concern Geography, hence with an incidence of $3.2 \%$ on the total number of credits over the five years, whereas the hours of teaching Geography (two) in primary education amount to $6.6 \%$ of the total hours per week, in each of the five years of primary school. This disproportion of course affects the degree of geographic preparation of the future teacher.

Since the teaching program is organized in semesters, geographical and space education, called the Teaching of Geography, including the basic contents of the discipline of Geography and their translation into practice of teaching, is taught only one semester, with a schedule of about six hours per week, even though considering that each university has full autonomy in the construction of the schedule of classes.

Considering that there is a total amount of hours including the hours of the course and those for laboratory activities, each teacher has to decide how to organize his lessons: either keeping the lab time at the end of the hours devoted to different aspects more specifically disciplinary, or alternating the hours of frontal lecture and lab hours. Of course, with only a few tens of hours at his disposal, the teacher must be able to provide opportunities for the consolidation of geographical knowledge, bearing in mind that some of the students may not have followed any teaching of Geography during the entire course of study in high school, for the acquisition of specific disciplinary teaching skills - the methods and tools of teaching Geography - and ultimately for testing through simulated situations of teaching practices (Rocca, 2012). These are very ambitious goals to achieve considering the limited amount of hours and that the students, according to different locations, can vary from a minimum of 30 to a maximum of a few hundred. 


\section{CONTENTS, GOALS AND EVALUATI ON OF GEOGRAPHI CAL TEACHI NG}

The choice of topics to be proposed during the course is at the discretion of the teacher who, however, has two fundamental reference texts. First of all, the decree establishing the course of studies, but very succinctly and very general, and moreover, the text National Guidelines for the curriculum of pre-school and of the first cycle of education (2012) that should be even more significant and ethically binding, as it shows the subdivision of the learning goals related to the three years of kindergarten, the first three years and the last two years of primary school and the corresponding objectives for the skill development, the latter related to the entire path of pre-school and similar to the five-year period for the primary school.

For example, the objectives for primary school, divided into those to be achieved at the end of the third class, and those who are to be achieved at the end of the fifth class, are aggregated into four main categories: orientation, language of geo-graphicity, landscape, region, and territorial system (Giorda, 2011). They refer to the following goals for the development of competences:

a) the student is oriented in the surrounding space and on maps, using topological references and cardinal points;

b) the student uses the language of geo-graphicity to interpret maps, realize simple cartographic sketches and thematic maps, plan routes and itineraries;

c) the student obtains geographic information from a plurality of sources (cartographic and satellite, digital, photographic, artistic and literary);

d) the student recognizes the elements and the main geographic "objects" that characterize the physical landscapes (mountains, hills, plains, volcanoes, etc.), paying particular attention to those in Italy, and identifies similarities and differences with the main European landscapes and with other continents;

e) the student captures in the world's historical landscapes the progressive transformations carried out by humans on the natural landscape;

f) the student realizes that the geographic space is a territorial system, consisting of physical and human elements linked by relations of connection and/or interdependence.

Like in every examination of the Italian university system, the evaluation of the geographical learning level of each student is made out of thirty (from a minimum of 18/30 to a maximum of 30/30 and any additional honour). The final mark includes also an evaluation, just of approval, of the laboratory path, the attendance of which, like the attendance of the entire course, is not compulsory. The teacher has the power to identify the most 
THE ROLE OF GEOGRAPHY IN STARTING TEACHER TRAI NING FOR INFANT ...

appropriate ways to check the levels of learning acquired by students, both in terms of disciplinary knowledge and in relation to the practices of the laboratory, using written modalities, oral and, in the case of laboratories, including practical.

\section{References}

Giorda, C. (2011). L'insegnamento della Geografia e della Didattica della geografia nel nuovo Corso di Laurea in Scienze della formazione primaria, in «Ambiente Società Territorio», nn. 3-4, 33-39.

Guaran, A. (2012). Dalla geografia alle educazioni: spazialità, cura del territorio, cittadinanza, in Morri, R. (ed.), Insegnare il mare. Paesaggi costieri e vocazioni maritime, pp. 120-123. Roma: Carocci.

Rocca, L. (2012). La dimensione del laboratorio per la formazione degli insegnanti, in Morri, R. (ed.), Insegnare il mare. Paesaggi costieri e vocazioni maritime, pp. 133-139. Roma: Carocci. 